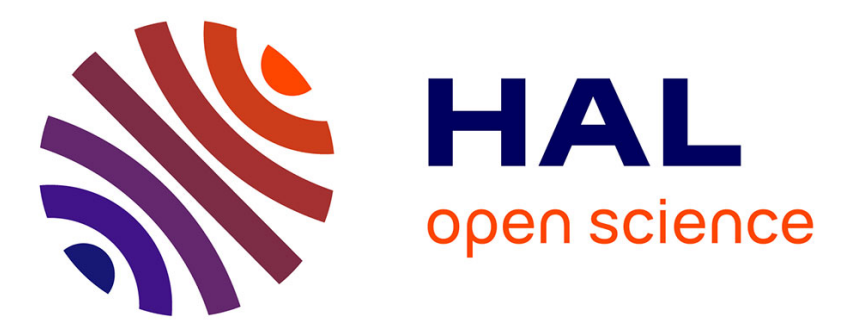

\title{
Electron acceleration by the lower-hybrid-drift instability at Mercury: an extended quasilinear model
}

Federico Lavorenti, Pierre Henri, Francesco Califano, Sae Aizawa, Nicolas

Andre

\section{- To cite this version:}

Federico Lavorenti, Pierre Henri, Francesco Califano, Sae Aizawa, Nicolas Andre. Electron acceleration by the lower-hybrid-drift instability at Mercury: an extended quasilinear model. Europlanet Science Congress 2021, Sep 2021, Virtual Congress, France. pp.EPSC2021-10. hal-03536603

\section{HAL Id: hal-03536603 https://hal.science/hal-03536603}

Submitted on 20 Jan 2022

HAL is a multi-disciplinary open access archive for the deposit and dissemination of scientific research documents, whether they are published or not. The documents may come from teaching and research institutions in France or abroad, or from public or private research centers.
L'archive ouverte pluridisciplinaire HAL, est destinée au dépôt et à la diffusion de documents scientifiques de niveau recherche, publiés ou non, émanant des établissements d'enseignement et de recherche français ou étrangers, des laboratoires publics ou privés.

\section{(c)(1)}

Distributed under a Creative Commons Attribution| 4.0 International License 
EPSC Abstracts

Vol. 15, EPSC2021-10, 2021

https://doi.org/10.5194/epsc2021-10

Europlanet Science Congress 2021

(C) Author(s) 2022. This work is distributed under

the Creative Commons Attribution 4.0 License.

\title{
Electron acceleration by the lower-hybrid-drift instability at Mercury: an extended quasilinear model
}

\author{
Federico Lavorenti ${ }^{1,2}$, Pierre Henri ${ }^{1,3}$, Francesco Califano ${ }^{2}$, Sae Aizawa ${ }^{4}$, and Nicolas Andre ${ }^{4}$ \\ ${ }^{1}$ Laboratoire Lagrance, Observatoire de la Côte d'Azur, Nice, France \\ ${ }^{2}$ Dipartimento di Fisica "E. Fermi", Università di Pisa, Pisa, Italy \\ ${ }^{3}$ LPC2E, CNRS-CNES-OSUC, Orléans, France \\ ${ }^{4}$ IRAP, CNRS-CNES-UPS, Toulouse, France
}

Density inhomogeneities are ubiquitous in space and astrophysical plasmas, in particular at contact boundaries between different media. They often correspond to regions that exhibits strong dynamics on a wide range of spatial and temporal scales. Indeed, density inhomogeneities are a source of free energy that can drive various plasma instabilities such as, for instance, the lower-hybrid-drift instability which in turn transfers energy to the particles through wave-particle interactions and eventually heats the plasma. Here, we address the role of this instability in the Hermean plasma environment were kinetic processes of this fashion are expected to be crucial in the plasma dynamics and have so far eluded the measurements of past missions (Mariner-X and MESSENGER) to Mercury.

The goal of our work is to quantify the efficiency of the lower-hybrid-drift instability to accelerate and/or heat electrons parallel to the ambient magnetic field.

To reach this goal, we combine two complementary methods: full-kinetic and quasilinear models.

We report self-consistent evidence of electron acceleration driven by the development of the lowerhybrid-drift instability using 3D-3V full-kinetic numerical simulations. The efficiency of the observed acceleration cannot be explained by standard quasilinear theory. For this reason, we develop an extended quasilinear model able to quantitatively predict the interaction between lower-hybrid fluctuations and electrons on long time scales, now in agreement with full-kinetic simulations results. Finally, we apply this new, extended quasilinear model to a specific inhomogeneous space plasma boundary: the magnetopause of Mercury, and we discuss our quantitative predictions of electron acceleration in support to future BepiColombo observations. 